\title{
Correction to: Hostility, compassion and role reversal in West Virginia's long opioid overdose emergency
}

\author{
Jeff Ondocsin ${ }^{1 \dagger}$, Sarah G. Mars ${ }^{1 \dagger}$, Mary Howe ${ }^{2}$ and Daniel Ciccarone ${ }^{1 *}$
}

\section{Correction to: Harm Reduct J (2020) 17:74 https://doi.org/10.1186/s12954-020-00416-w} After publication of the original article [1], the authors identified an error in Acknowledgements section. The below disclosures is missing.

"Dr. Ciccarone has received compensation in the past 36 months for: being on the Scientific Advisory Board for Celero Systems; providing expert testimony for Motley Rice LLP; being a one-time consultant for Arbor Pharmaceuticals; all outside the submitted work".

The original article has been corrected.

\begin{abstract}
Author details
${ }^{1}$ Heroin in Transition Study, Department of Family and Community Medicine, UCSF, University of California, 500 Parnassus Avenue, Milberry Union East, 3rd Floor, San Francisco, CA 94143, USA. ${ }^{2}$ Homeless Youth Alliance, PO Box 170427, San Francisco, CA 94117, USA.
\end{abstract}

Published online: 30 August 2021

\author{
Reference \\ 1. Ondocsin J, et al. Harm Reduct J. 2020;17:74. https://doi.org/10.1186/ \\ s12954-020-00416-w.
}

\section{Publisher's Note}

Springer Nature remains neutral with regard to jurisdictional claims in published maps and institutional affiliations. original author(s) and the source, provide a link to the Creative Commons licence, and indicate if changes were made. The images or other third party material in this article are included in the article's Creative Commons licence, unless indicated otherwise in a credit line to the material. If material is not included in the article's Creative Commons licence and your intended use is not permitted by statutory regulation or exceeds the permitted use, you will need to obtain permission directly from the copyright holder. To view a copy of this licence, visit http://creativecommons.org/licenses/by/4.0/. The Creative Commons Public Domain Dedication waiver (http://creativecommons.org/publicdomain/zero/1.0/) applies to the data made available in this article, unless otherwise stated in a credit line to the data. 